\title{
Thermal decomposition of some silver(I) carboxylates under nitrogen atmosphere
}

\author{
R. Szczęsny • E. Szłyk
}

Received: 14 February 2012/ Accepted: 8 May 2012/Published online: 17 June 2012

(c) The Author(s) 2012. This article is published with open access at Springerlink.com

\begin{abstract}
The thermal decomposition reactions of $\mathrm{CH}_{3} \mathrm{CH}_{2} \mathrm{C}\left(\mathrm{CH}_{3}\right)_{2} \mathrm{COOAg}$ (1), $\left(\mathrm{CH}_{3}\right)_{3} \mathrm{SiCH}_{2} \mathrm{COOAg}$ (2), $\mathrm{CF}_{3} \mathrm{COOAg}$ (3), $\left(\mathrm{CH}_{3}\right)_{3} \mathrm{CCOOAg}$ (4), $\mathrm{C}_{2} \mathrm{H}_{5} \mathrm{COOAg}$ (5), $\mathrm{C}_{3} \mathrm{~F}_{7} \mathrm{COOAg}(\mathbf{6}), \mathrm{C}_{6} \mathrm{~F}_{13} \mathrm{COOAg}(\mathbf{7})$ and $\left(\mathrm{CF}_{2}\right)_{3}(\mathrm{COOAg})_{2}(\mathbf{8})$ were studied in $\mathrm{N}_{2}$ atmosphere using thermogravimetry (TG), derivative thermogravimetry and differential thermal analysis. Characterized compounds decomposed in one- or multistep processes with metallic silver formation in the range 215-465 ${ }^{\circ} \mathrm{C}$. TG-IR studies of gases evolved during thermolysis revealed products of decomposition, such as carbox ylic acids, $\mathrm{CO}_{2}$ and recombination reactions.
\end{abstract}

Keywords Silver carboxylate - Thermal analysis . Gaseous products

\section{Introduction}

'Silver(I) carboxylates and their complexes with tertiary phosphines have found applications as precursors for chemical vapor deposition (CVD) [1-7]. Silver thin layers produced by this method can be applied in microelectronic circuits, catalysis, as a bactericidal coatings [8], as mirrors and other applications [4, 9]. The knowledge about thermal properties of precursors is important for the evaporation parameters and determination of the metallated species which can be transported in the gas phase. Furthermore, the weight loss during the experiment can be indicative of volatility and the cleanliness of the thermolysis mechanism.

R. Szczęsny $(\bowtie) \cdot$ E. Szłyk

Faculty of Chemistry, Nicolaus Copernicus University,

87100 Toruń, Poland

e-mail: roszcz@umk.pl
The precursors should be volatile and decompose to a metal at relatively low temperature and pressure in CVD apparatus. The data on gas phase composition and stability during transport in the CVD equipment are used in selection of the appropriate conditions [10]. These parameters are necessary for ascertaining of the evaporation temperature, CVD heating regime and finally the precursor decomposition temperature on the substrate surface in the last stage of the layer formation. The thermal stability and thermodynamic data on compounds applied for CVD can also be useful in selection of the most promising precursors.

Generally, silver(I) carboxylates are thermally stable and decompose to the metallic silver and volatile organic and inorganic products at a wide range of temperatures [11-15] depending on the carboxylate residue. Reported informations of silver(I) carboxylates proposed the following scheme of the decomposition reaction:

$\mathrm{CH}_{3}\left(\mathrm{CH}_{2}\right)_{n} \mathrm{COOAg} \rightarrow \mathrm{Ag}+\mathrm{CO}_{2}+\mathrm{CH}_{3}\left(\mathrm{CH}_{2}\right)_{n} \mathrm{CH}_{3}$

However, other studies suggested formation of the silver(I) oxide (unstable greater than $300{ }^{\circ} \mathrm{C}$ ) in the first stage of this process connected with formation of the anhydride of the corresponding acid. In the further stage, the anhydride and silver oxide undergo transformation giving final products: $\mathrm{RCOOH}$ and $\mathrm{Ag}^{0}$ [11]. So far, only few studies reported concerning this matter and our study is intended to extend this issue.

\section{Experimental}

Materials and synthesis

Carboxylic acids: $\mathrm{CH}_{3} \mathrm{CH}_{2} \mathrm{C}\left(\mathrm{CH}_{3}\right)_{2} \mathrm{COOH}(96 \%),\left(\mathrm{CH}_{3}\right)_{3}$ $\mathrm{SiCH}_{2} \mathrm{COOH}(99 \%), \mathrm{CF}_{3} \mathrm{COOH}(99 \%),\left(\mathrm{CH}_{3}\right)_{3} \mathrm{CCOOH}$ 
(99\%), $\quad \mathrm{C}_{2} \mathrm{H}_{5} \mathrm{COOH} \quad(99.5 \%), \quad \mathrm{C}_{3} \mathrm{~F}_{7} \mathrm{COOH} \quad(98 \%)$, $\mathrm{C}_{6} \mathrm{~F}_{13} \mathrm{COOH}(99 \%)$ and $\left(\mathrm{CF}_{2}\right)_{3}(\mathrm{COOH})_{2}(97 \%)$ were purchased from Aldrich, whereas $\mathrm{AgNO}_{3}$ (>99.9\%), $\mathrm{KNO}_{3}(99 \%), \mathrm{NaHCO}_{3}(99.5 \%), \mathrm{C}_{2} \mathrm{H}_{5} \mathrm{OH}$ from $\mathrm{POCH}$ (Poland) and were used as received. All salts were prepared according to previously reported procedures [16-18]. In the case of (1), (2), (4) and (5), appropriate carboxylic acids and potassium nitrate were suspended in a water-ethanol solution (1:1), heated to $40{ }^{\circ} \mathrm{C}$ and stirred, followed by silver nitrate addition. The obtained precipitate was filtered, washed with water, ethanol and dried. The salts (3) and $(\mathbf{6})-(\mathbf{8})$ were synthesized by the reaction of fluorinated carboxylic acids and silver carbonate.

Apparatus and experimental methods

TG/DTG-DTA measurements were performed on SDT 2960 TA analyser. Decomposition processes were studied in dynamic atmospheres of $\mathrm{N}_{2}(99.999 \%)$ at $100 \mathrm{ml} \mathrm{min}^{-1}$. The heating rate was $10^{\circ} \mathrm{C} \min ^{-1}$ and samples mass was 3-12 mg. Gaseous products of thermal decomposition were detected by a FT-IR BioRad Excalibur spectrophotometer equipped with thermal connector for gases evolved from TA SDT 2960 analyser. Powder X-ray diffraction data for the residues from thermal analysis were obtained with a Philips $\mathrm{X}$ 'PERT diffractometer using $\mathrm{Cu} \mathrm{K} \alpha$ radiation.

\section{Results and discussion}

Thermal analysis results

The TG/DTG-DTA analyses of (1)-(8) were carried out to give an information of the possible decomposition temperatures and also the relative stability of the salts. The results are summarized in Table 1. Decomposition of (1) proceeds in one endothermic stage started at $150{ }^{\circ} \mathrm{C}$ (DTA curve: $T_{\max }=195{ }^{\circ} \mathrm{C}$ ) and is completed at $250{ }^{\circ} \mathrm{C}$ (Fig. 1a). The metallic silver is the final product with the presence of carbonaceous species, what is evident from XRD studies of the residue in the crucible [19]. Salt $\left(\mathrm{CH}_{3}\right)_{3} \mathrm{SiCH}_{2} \mathrm{COOAg}$ (2) is thermally stable up to $135{ }^{\circ} \mathrm{C}$ and decompose greater than this temperature (Fig. 1b). This process is connected with one exothermic effect (DTA) with the maximum appeared at $210{ }^{\circ} \mathrm{C}$. Metallic silver is formed greater than $215^{\circ} \mathrm{C}$. In the case of $\mathrm{CF}_{3} \mathrm{COOAg}$ (3), DTA curve indicates four peaks (Fig. 1c). The first one is a strong endothermic transition at $260{ }^{\circ} \mathrm{C}$, which is connected with a slight mass loss and probably corresponds to the melting point. The next stage (DTA: exo, $T_{\max }=350{ }^{\circ} \mathrm{C}$ ) is resulted from the main thermal decomposition process, and weight loss is about $48 \%$. Then, two small endothermic peaks appear at 415 and
$430{ }^{\circ} \mathrm{C}$. The corresponding mass loss on the TG is about $3 \%$. Silver pivalate (4) decomposes in one-stage process with $T_{\max }$ on DTA curve at $235^{\circ} \mathrm{C}$ (exothermic peak) (Fig. 1d). As distinct from the others, thermolysis of (5)(6) proceeds in two stages. Figure $2 \mathrm{a}$ shows the characteristic features of heating silver propionate (5). The first stage occurs between 80 and $130{ }^{\circ} \mathrm{C}$ (TG) and involves a mass loss of $3.2 \%$. The second one is associated with a mass loss amount to $39.2 \%\left(160-265{ }^{\circ} \mathrm{C}\right)$. Three peaks are observed in the DTA curve; peaks 1 (endo, $100^{\circ} \mathrm{C}$ ) and 3 (exo, $245^{\circ} \mathrm{C}$ ) are well defined in both the DTA and DTG curves, but the weak peak 2 (endo, $175^{\circ} \mathrm{C}$ ) is visible only on DTA data.

The TG, DTA and DTG curves of silver heptafluorobutyrate (6) are presented in Fig. 2b. Analysis of the DTA data revealed two exothermic effects at 320 and $345{ }^{\circ} \mathrm{C}$ that are connected with a rapid weight loss. Furthermore, endothermic peak occurs at $290{ }^{\circ} \mathrm{C}$. In the case of $\mathrm{C}_{6} \mathrm{~F}_{13}$ COOAg (7), DTA curve displays three peaks maximized at 100,145 and $275{ }^{\circ} \mathrm{C}$ (Fig. 2c). All peaks are linked with weight loss: $\sim 4.5, \sim 3$ and $61.9 \%$, respectively. Silver hexafluoroglutarate (8) undergoes decomposition in three steps with the DTA peak temperatures at 325,350 and $370{ }^{\circ} \mathrm{C}$ (Fig. 2d). The first of them is very sharp. Thermolysis gives rise to the three weight losses in TG curve (about 37, 6 and $9 \%$ ).

The results point to higher thermal stability of fluorinated carboxylates. For most of analysed salts, mass of residue remaining is close to expected for the formation of metallic silver. Occurred slight discrepancy derived from the presence of small amounts of carbon in the solid product. Differences between calculated and experimental data are more significant for the compounds (4) and (5) and may be caused by the specificity of decomposition mechanism. From the above-presented results, it can be seen that described carboxylates can be potentially precursors in CVD process because they decomposed in a relatively low temperatures. However, it is noteworthy that this is only one of several necessary attributes of a good precursor.

\section{TG-IR results}

Thermolysis is in many cases a one-particle reaction, but in fact apparently simple reactions are complicated processes $[20,21]$. Our earlier TG-IR studies confirmed that $\mathrm{CH}_{3} \mathrm{CH}_{2} \mathrm{C}\left(\mathrm{CH}_{3}\right)_{2} \mathrm{COOAg}(\mathbf{1})$ and $\left(\mathrm{CH}_{3}\right)_{3} \mathrm{SiCH}_{2} \mathrm{COOAg}(\mathbf{2})$ decomposed with formation of several products originating from direct decomposition of molecules such as $\mathrm{CO}_{2}$, and from recombination reactions $[12,18]$. The present examination (with a higher heating rate) point to carbon dioxide and carboxylic acids emission. In the case of silver 2,2dimethylbutyrate, the following bands were present: $\nu \mathrm{CH}$, $2981 / 2946 / 2895 ; \mathrm{CO}_{2}, 2360,2332 ; v \mathrm{C}=\mathrm{O}, 1767 ; \delta \mathrm{CH}_{2}$, 
Table 1 Results of thermal analysis of (1)-(8) in $\mathrm{N}_{2}$ atmosphere

\begin{tabular}{|c|c|c|c|c|c|c|}
\hline \multirow[t]{2}{*}{ Compound } & \multirow[t]{2}{*}{ Heat effect DTA } & \multicolumn{3}{|c|}{ Temperature $/{ }^{\circ} \mathrm{C}$} & \multicolumn{2}{|c|}{ Residue/\% } \\
\hline & & $T_{\text {init }}$ & $T_{\max }$ & $T_{\mathrm{f}}$ & Calc. & Found \\
\hline $\mathrm{CH}_{3} \mathrm{CH}_{2} \mathrm{C}\left(\mathrm{CH}_{3}\right)_{2} \mathrm{COOAg}(\mathbf{1})$ & Endo & 150 & 240 & 250 & 48.4 & 48.0 \\
\hline$\left(\mathrm{CH}_{3}\right)_{3} \mathrm{SiCH}_{2} \mathrm{COOAg}(\mathbf{2})$ & Exo & 135 & 200 & 215 & 45.1 & 46.9 \\
\hline \multirow[t]{3}{*}{$\mathrm{CF}_{3} \mathrm{COOAg}(3)$} & Endo & 200 & 260 & - & 48.8 & 48.6 \\
\hline & Exo & - & 335 & - & & \\
\hline & Endo/endo & - & $410 / 430$ & 465 & & \\
\hline$\left(\mathrm{CH}_{3}\right)_{3} \mathrm{CCOOAg}(\mathbf{4})$ & Exo & 155 & 225 & 235 & 51.6 & 59.1 \\
\hline \multirow[t]{2}{*}{$\mathrm{C}_{2} \mathrm{H}_{5} \mathrm{COOAg}(\mathbf{5})$} & Endo & 80 & 100 & 130 & 59.6 & 57.6 \\
\hline & Exo & 160 & 240 & 265 & & \\
\hline \multirow[t]{2}{*}{$\mathrm{C}_{3} \mathrm{~F}_{7} \mathrm{COOAg}(\mathbf{6})$} & Endo/exo & 250 & 320 & - & 33.6 & 32.8 \\
\hline & Exo & - & 335 & 355 & & \\
\hline \multirow[t]{3}{*}{$\mathrm{C}_{6} \mathrm{~F}_{13} \mathrm{COOAg}(7)$} & Endo & 70 & 95 & - & 29.1 & 30.7 \\
\hline & Endo & - & 140 & 165 & & \\
\hline & Endo & 265 & 280 & 310 & & \\
\hline \multirow[t]{3}{*}{$\left(\mathrm{CF}_{2}\right)_{3}(\mathrm{COOAg})_{2}(\mathbf{8})$} & Endo & 110 & 325 & - & 47.5 & 47.3 \\
\hline & Endo & - & 355 & - & & \\
\hline & Endo & - & 375 & 385 & & \\
\hline
\end{tabular}

$T_{\text {init }}$ initial temperature, $T_{\max }$ maximum temperature, $T_{\mathrm{f}}$ final temperature

Fig. 1 TG, DTG and DTA curves of $\mathrm{CH}_{3} \mathrm{CH}_{2} \mathrm{C}\left(\mathrm{CH}_{3}\right)_{2} \mathrm{COOAg}(\mathbf{1})$ (a), $\left(\mathrm{CH}_{3}\right)_{3} \mathrm{SiCH}_{2} \mathrm{COOAg}(\mathbf{2})$ (b), $\mathrm{CF}_{3} \mathrm{COOAg}(3)$ (c) and $\left(\mathrm{CH}_{3}\right)_{3} \mathrm{CCOOAg}(\mathbf{4})(\mathbf{d})$
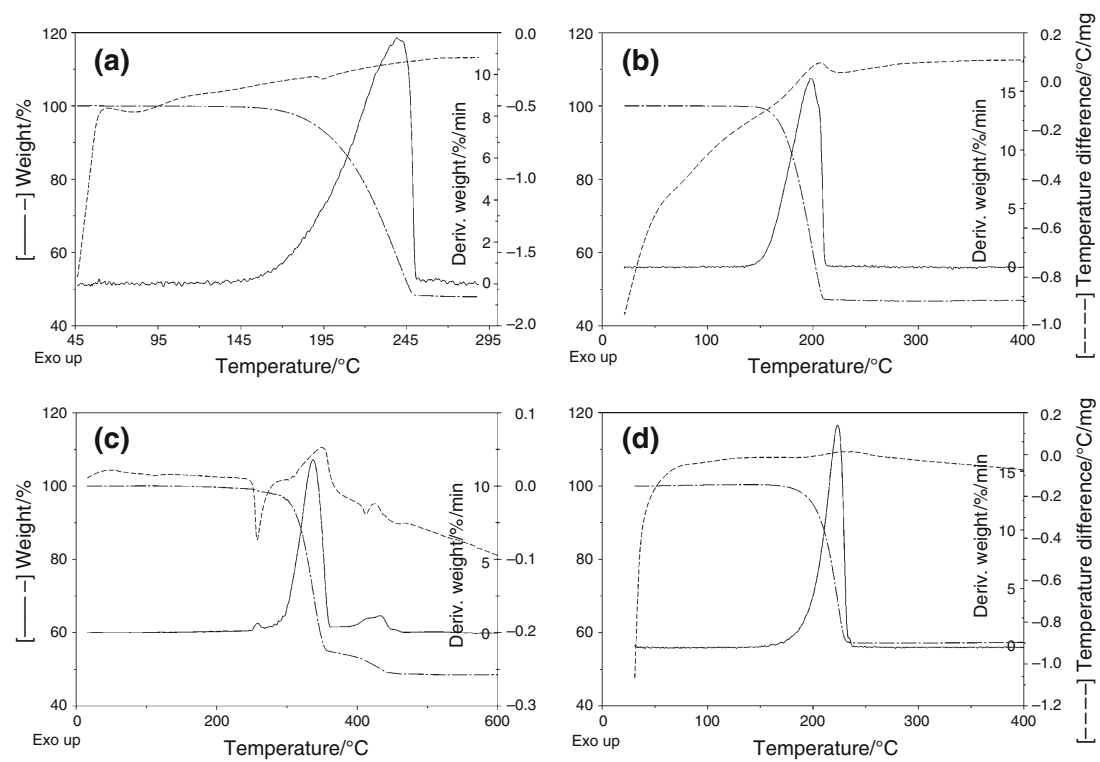

$1473 ; \delta \mathrm{CH}_{3}$ or $\delta \mathrm{OH}, 1394 ; v \mathrm{CCO}, 1115 ; \gamma \mathrm{C}=\mathrm{O}, 578 \mathrm{~cm}^{-1}$ (Fig. 3).

The result of TG-IR measurement performed for (3) is presented in Fig. 4. In this case, bands derived from carbon dioxide (2359 and $688 \mathrm{~cm}^{-1}$ ) were observed in the maximum decomposition rate. The second main volatile product was $\mathrm{CF}_{3} \mathrm{CFO}$, which was also identified in earlier studies concerning transitions metals trifluoroacetates [22, 23]. This assumption is confirmed by the presence of bands at: 1896, 1240, 1210 and $1097 \mathrm{~cm}^{-1}$ [24, 25]. These results indicate that for this compound, recombination processes within $\mathrm{CF}_{3} \mathrm{COO}^{-}$also take place. Furthermore, two small peaks at 2180 and $2108 \mathrm{~cm}^{-1}$ seemed to be evidence of the presence of carbon monoxide [26].

The IR spectra for $\left(\mathrm{CH}_{3}\right)_{3} \mathrm{CCOOAg}$ (4) reveal absorption bands derived from carbon dioxide $\left(2359,669 \mathrm{~cm}^{-1}\right)$ and bands at 2981 and $2946 \mathrm{~cm}^{-1}(v \mathrm{CH})$. Besides that intensive signals occur at 1,771 (asymmetric band of $\mathrm{COO}), 1117 \mathrm{~cm}^{-1}$ and the others at $1315,1032,888$ and $577 \mathrm{~cm}^{-1}$. These spectra are more similar to the spectra of pivalic acid than for anhydride, so we presume the presence of $\left(\mathrm{CH}_{3}\right)_{3} \mathrm{CCOOH}$. 
Fig. 2 TG, DTG and DTA curves of $\mathrm{C}_{2} \mathrm{H}_{5} \mathrm{COOAg}(\mathbf{5})(\mathbf{a})$, $\mathrm{C}_{3} \mathrm{~F}_{7} \mathrm{COOAg}(\mathbf{6})(\mathbf{b})$,

$\mathrm{C}_{6} \mathrm{~F}_{13} \mathrm{COOAg}(7)(\mathbf{c})$ and

$\left(\mathrm{CF}_{2}\right)_{3}(\mathrm{COOAg})_{2}(\mathbf{8})(\mathbf{d})$
Fig. 3 FT-IR spectrum of the volatile products evolved during thermal decomposition of $\mathrm{CH}_{3} \mathrm{CH}_{2} \mathrm{C}\left(\mathrm{CH}_{3}\right)_{2} \mathrm{COOAg}(\mathbf{1})$ $\left(230-245{ }^{\circ} \mathrm{C}\right)$
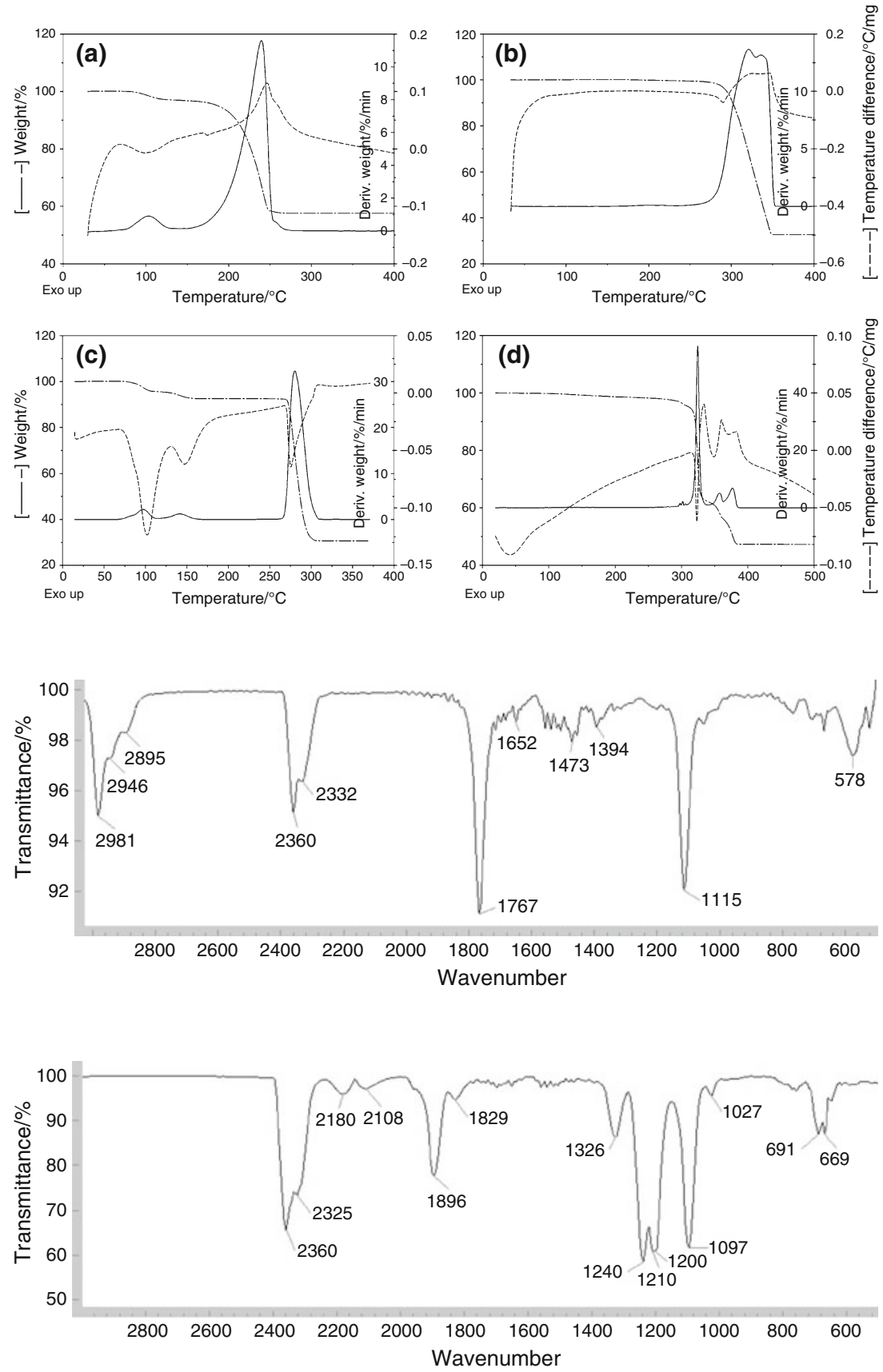

Fig. 4 FT-IR spectrum of the volatile products evolved during thermal decomposition of $\mathrm{CF}_{3} \mathrm{COOAg}(3)$ $\left(325-350{ }^{\circ} \mathrm{C}\right)$
In the case of silver propionate (5), thermolysis consists of two isolated processes. In the first stage, the intensity of the bands is very small and only two of them at 1790 and $1773 \mathrm{~cm}^{-1}(\nu \mathrm{COO})$ are detected. Unfortunately, based on this data, it was impossible to determine the composition of a vapor phase. Above-mentioned signals also appeared in spectra recorded at the second step of decomposition. Additionally, broad bands at 1148 and $1060 \mathrm{~cm}^{-1}$ (C-O stretching absorption) and bands resulted from $\mathrm{CH}$ and $\mathrm{CO}_{2}$ vibrations also appear. The above results indicate the presence of diluted monomeric propionic acid in the vapor phase.
For $\mathrm{C}_{3} \mathrm{~F}_{7} \mathrm{COOAg}(6)$ (at a temperature about $280{ }^{\circ} \mathrm{C}$ ), carbon dioxide and fluorocarbon species (1251 and $1213 \mathrm{~cm}^{-1}$, respectively) are observed. At $290{ }^{\circ} \mathrm{C}$, additional bands at 1391 and $1334 \mathrm{~cm}^{-1}$ (s) (from C-F groups) and 1792,1148 and $1035 \mathrm{~cm}^{-1}(\mathrm{~m})$ occur, which can be assigned to the heptafluorobutyric acid. It should be noted that the intensity of the $v \mathrm{COO}$ band is much lower than for others carboxylates (Fig. 5).

The next salt (7), with longer fluorocarbon chain, decomposed in a different mode. At the two first stages of thermolysis, only bands from carbon dioxide are observed. Greater than $280^{\circ} \mathrm{C}$, strong sharp bands at $1,244(v \mathrm{C}-\mathrm{F})$, 

volatile products evolved during thermal decomposition of $\mathrm{C}_{3} \mathrm{~F}_{7} \mathrm{COOAg}(\mathbf{6})$ $\left(300-320{ }^{\circ} \mathrm{C}\right)$
Fig. 5 FT-IR spectrum of the

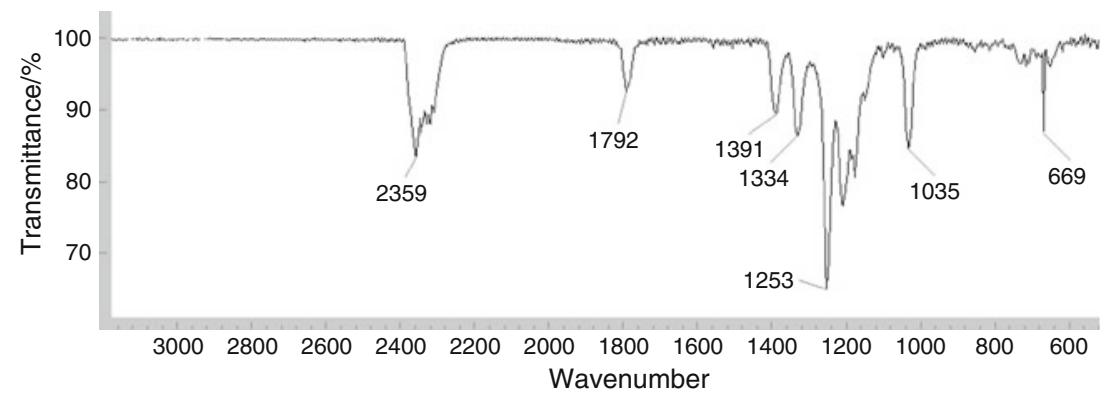

Fig. 6 FT-IR spectrum of the volatile products evolved during thermal decomposition of $\left(\mathrm{CF}_{2}\right)_{3}(\mathrm{COOAg})_{2}(\mathbf{8})$ $\left(355-370{ }^{\circ} \mathrm{C}\right)$

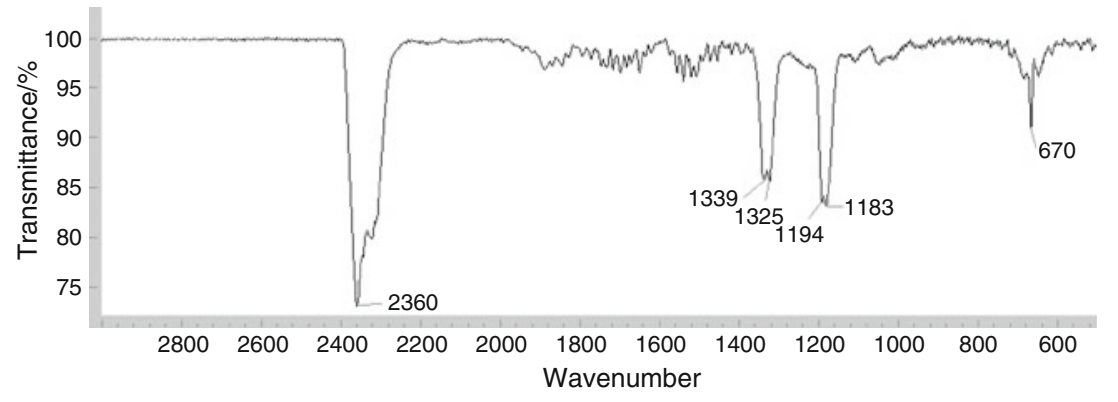

$1781 \mathrm{~cm}^{-1}$ (vCOO) and additional bands at 1367, 1318, $1141,1091,861,813$ and $743 \mathrm{~cm}^{-1}$ are found on spectra of the volatile products. During the decomposition process of silver hehafluoroglutarate $(\mathbf{8})$, only $\mathrm{CO}_{2}$ and small bands at 1187 and $1050 \mathrm{~cm}^{-1}$ are registered less than $335{ }^{\circ} \mathrm{C}$. Increasing the temperature causes the formation of additional bands at 1885 and $1849 \mathrm{~cm}^{-1}$ (vCOO). Simultaneous changes in the range $1000-1300 \mathrm{~cm}^{-1}$ are detected (bands at 1201 (s), 1137, 948, $894 \mathrm{~cm}^{-1}$ ). Furthermore, $\mathrm{C}=\mathrm{O}$ absorption bands appear. These results allow to assume that $\mathrm{CO}_{2}$ and $\left(\mathrm{CF}_{2}\right)_{3}(\mathrm{COOH})_{2}$ are the main gaseous products at temperature less than $350{ }^{\circ} \mathrm{C}$. The spectra registered greater than $350{ }^{\circ} \mathrm{C}$ correspond to the two successive stages of the thermal decomposition (see Fig. 6). In this case, there is no evidence of the presence of the COO group. The spectrum revealed bands derived from carbon dioxide and two doublets at $1339 / 1325$ and $1194 / 1183 \mathrm{~cm}^{-1}$, indicating the presence of $\mathrm{C}_{2} \mathrm{~F}_{4}$ [27].

TG-IR spectra analyses do not determine the presence of silver-containing species in the gas phase. However, these results may derive not only from the absence of them but also from too small concentration to be detected by an applied method. On the other hand, variable temperature mass spectra [28] pointed on $\left[\mathrm{Ag}_{2}(\mathrm{OOCR})\right]^{+}$as main stable silver species and this dimeric system may be a volatile precursor in CVD reactor. We can also conclude that for both aliphatic and fluorinated silver(I) carboxylates, thermolysis resulted primarily in the formation of acids and carbon dioxide in the gas phase. It is also worth mentioning that in all cases, $\mathrm{CO}_{2}$ is always recorded as the first gaseous product of thermal decomposition. Furthermore, the fragmentations and transformations of the acid residue take place.

\section{Conclusions}

Thermal decomposition of studied salts resulted in silver, what is evident from the TG calculation, XRD and results of the previous studies. The data indicate that carboxylates usually decompose without a melting point (or a melting point is connected with thermolysis) and cannot be efficiently evaporated. Aliphatic salts decompose in lower temperatures than fluorinated ones. This feature most probably comes out from the lower stability of Ag-O bond. In the case of aliphatic acids, they became less covalent than in perfluorinated analogs.

Analysis of the composition of vapors, formed during thermolysis in nitrogen atmosphere, indicates carbon dioxide and appropriates acids as the main products. Presence of $\mathrm{RCOOH}$ might correspond with a theory that $\mathrm{R}-\mathrm{CO}-\mathrm{O}-\mathrm{CO}-\mathrm{R}$ and $\mathrm{Ag}_{2} \mathrm{O}$ undergo transformation to $\mathrm{RCOOH}$ and $\mathrm{Ag}^{0}$. In this case, there is a chance that the described transitions are so fast, that we cannot register the anhydride.

Open Access This article is distributed under the terms of the Creative Commons Attribution License which permits any use, distribution, and reproduction in any medium, provided the original author(s) and the source are credited.

\section{References}

1. Haase T, Kohse-Höinghaus K, Bahlawane N, Djiele P, Jakob A, Lang H. CVD with Tri-nbutylphosphine silver(I) complexes: mass spectrometric investigations and depositions. Chem Vap Deposition. 2005;11(4):195-205.

2. Han J, Shen Y, Li Ch, Li Y, Pan Y. Synthesis and characterization of triphenylphosphine stabilized silver $\alpha, \beta$-unsaturated 
carboxylate: Crystal structure of $\left[\mathrm{Ag}\left(\mathrm{O}_{2} \mathrm{CCH}=\mathrm{C}\left(\mathrm{CH}_{3}\right)_{2}\right)\left(\mathrm{PPh}_{3}\right)_{2}\right]$. Inorg Chim Acta. 2005;358:4417-22.

3. Hampen-Smith MJ, Kodas TT. Chemical vapor deposition of metals. Part 1. An overview of CVD processes. Chem Vap Deposition. 1995;1(1):8-23.

4. Hampen-Smith MJ, Kodas TT. The chemistry of metal CVD. Weinheim: VCH; 1994.

5. Dryden NH, Vittal JJ, Pudderphatt RJ. New precursors for chemical vapor deposition of silver. Chem Mater. 1993;5(6): 765-6.

6. Schmidt H, Shen Y, Leschke M, Haase Th, Kohse-Höinghaus K, Lang H. Synthese und Verwendung in der Silber-CVD. J Organomet Chem. 2003;669:25-31.

7. Edwards DA, Harker RM, Mahon MF, Molloy KC. Aerosolassisted chemical vapour deposition (AACVD) of silver films from triorganophosphine adducts of silver carboxylates, including the structure of $\left[\mathrm{Ag}\left(\mathrm{O}_{2} \mathrm{CC}_{3} \mathrm{~F}_{7}\right)\left(\mathrm{PPh}_{3}\right)_{2}\right]$. Inorg Chim Acta. 2002; 328:134-46.

8. Kim H, Jeong H, Bao SJ, Zhang G. Enhanced photocatalytic activity of magnetic $\mathrm{TiO}_{2}$ photocatalyst by silver deposition. Mater Lett. 2005;59:2194-8.

9. Ting Ch-J, Chen Ch-F, Chou CP. Experimental study of a silver layer on an antireflection subwavelength-structured surface. IEEE Phot Tech Lett. 2008;20(13):1196-8.

10. Vourlias G, Chaliampalias D, Pavlidou E, Stergioudis G, Chrissafis K. Examination of zinc coatings on copper substrates by thermal analysis. $\mathrm{J}$ Therm Anal Calorim. Online First $^{\mathrm{TM}}$, 11 January 2012.

11. Prasad R, Sulaxna, Kumar A. Kinetics of thermal decomposition of iron(III) dicarboxylate complexes. J Therm Anal Calorim. 2005;81:441-50.

12. Uvarov NF, Burleva LP, Mizen MB, Whitcomb DR, Zou C. Conductivity of long-chain silver carboxylates and their thermal decomposition products. Solid State Ionic. 1998;107:31-40.

13. Burleva LP, Andreev VM, Boldyrev VV. Thermal decomposition of silver carboxylates. J Therm Anal. 1988;33:735-9.

14. Judd MD, Plankett BA, Pope MI. The thermal decomposition of calcium, sodium, silver and copper(II) acetates. J Therm Anal. 1974;6:555-63.

15. Liu X, Lu S, Zhang J, Cao W. Silver behenate under high pressure: a powder diffraction study. Thermochim Acta. 2006;440: $1-6$.

16. Szlyk E, Łakomska I, Grodzicki A. Thermal and spectroscopic studies of the $\operatorname{Ag}(\mathrm{I})$ salts with fluorinated carboxylic and sulfonic acid residues. Thermochim Acta. 1993;223:207-12.
17. Szłyk E, Szymańska I, Szczęsny R. Multinuclear NMR and thermal studies of new silver(I) silylated carboxylates with triphenylphosphine. Polish J Chem. 2005;79:627-35.

18. Szymańska I, Piszczek P, Szczęsny R, Szłyk E. Thermal and MS studies of silver(I) 2,2-dimethylbutyrate complexes with tertiary phosphines and their application for CVD of silver films. Polyhedron. 2007;26:2440-8.

19. Powder diffraction File, Sets 4-783. International Centre for Diffraction Data (JCPDS), USA; 1977.

20. Nazir R, Mazhar M, Wakeel T, Akhtar MJ, Siddique M, Nadeem M, Khan NA, Shah MR. Pyrolysis mechanism of trisbipyridineiron(II) chloride to iron nanoparticles. J Therm Anal Calorim. Online First ${ }^{\mathrm{TM}}$, 13 September 2011.

21. Rejitha KS, Ichikawa T, Mathew S. Investigations on the thermal behaviour of $\left[\mathrm{Ni}\left(\mathrm{NH}_{3}\right)_{6}\right]\left(\mathrm{NO}_{3}\right)_{2}$ and $\left[\mathrm{Ni}(\mathrm{en})_{3}\right]\left(\mathrm{NO}_{3}\right)_{2}$ using TGMS and TR-XRD under inert condition. $\mathrm{J}$ Therm Anal Calorim. 2012;107:887-92.

22. Eloussifi H, Farjas J, Roura P, Camps J, Dammak M, Ricart S, Puig T, Obradors X. Evolution of yttrium trifluoroacetate during thermal decomposition. J Therm Anal Calorim. 2012;108: 589-96.

23. Baillie MJ, Brown DH, Moss KC, Sharp DWA. Anhydrous metal trifluoroacetates. J Chem Soc (A). 1968;3110-3114.

24. Berney CV. Infrared spectra of trifluoroacetic acid and trifluoroacetic anhydride. Spectrochim Acta. 1971;27A:2445-60.

25. Majima T, Sugita K, Nakao A, Matsunuma S, Abe K. Synthesis of thin layer of fluorinated polymer by laser CVD. Direct synthesis of perfluoropolyether thin film on surface by oxidative polymerization of a perfluoropropene-oxygen mixture using an ArF excimer laser. J Photopolym Sci Technol. 1993;6(3):421-8.

26. Seasholtz MB, Pence LE, Moe OA. Determination of carbon monoxide in automobile exhaust by FTIR spectroscopy: an instrumental analysis laboratory experiment. J Chem Educ. 1988; 12(9):820-3.

27. National Institute of Standarts and Technology (NIST), http://webbook.nist.gov/chemistry/. Accessed 12 Jan 2012.

28. Adams SK, Edwards DA, Richards R. Silver(I) carboxylates. I. mass spectra and low frequency infrared spectra. Inorg Chim Acta. 1975;12:163-6. 